удК: $930(477.7)(=112.2): 330.34: 316.728$ «185/190»

D0I: $10.26661 /$ zhv-2019-1-53-07

\title{
Pre-Revolutionary Historiography of the Socio-Economic and Cultural Life of the German-Speaking Population of the South Ukraine in the Middle of the 19th and Early 20th Centuries
}

\author{
0. V. Zamuruytsev \\ Bogdan Khmelnitsky Melitopol State Pedagogical University \\ sarmat254@ukr.net
}

\author{
N. A. Shkoda \\ Bogdan Khmelnitsky Melitopol State Pedagogical University \\ igor.schckoda@yandex.ua
}

Key words: foreign colonization; German colonists; Mennonites; colonial ownership of land; agriculture; commodity economy; extensive development.
The history of the research of the socio-economic and the cultural life of the German and Mennonite settlements on the example of the territory of thosedays of Katerynoslavska and Tavriya provinces (gubernia) in the middle of the 19th - early 20th centuries is analyzed inthe article. On the base ofappropriate material,the authorsmade the attempt to determine the most typical features and the directions of the development of this process and to find out its general tendencies.

Analyzing the general picture of the development of the pre-revolutionary historiography of the problem, it should be noted that during this period the foundations of its study were laid and the conditions for the further scientific research were created. It is determined that the historiography of the chosen problem at that time was characterized mainly the descriptive character and the lack of the clear methodology of the scientific research. Their researchers were not most often the professional historians, but the single personalities who, by the nature of their activities, were dealt with the colonial environment. The basis of their work was the documents of the state audits and the provincial statistics, the materials of the colonial and the departmental archives, the legislative acts, etc., and also the own observations. Among the literature of that time, we can find two directions which are differed in character and the individual accents in the research of the history of Germans and Mennonites in Russia. One of them, which is combined the works which are devoted directly to the general history of the German colonization in the Russian Empire. The general-historical aspect of this problem is directly dominated, and in many cases these researches only partially are touched the Southern regions of the modern Ukraine.

Another direction was related to literature, which is considered the German question only as the part of the whole history of the South Ukraine, at its regional level and only in the general context of the defined theme. A lot of attention was paid here to more specific, in particular, the economic questions, which were investigated with the help of the considerable statistical material, which was gathered during the numerical provincial censuses.

It should be noted that, despite the insufficient scientific character of many such publications, they laid the foundations for further definition of the mentioned themeof next (Soviet) period. 


\title{
Дореволюційна історіографія соціально-економічного та культурного життя німецькомовного населення Південної України середини XIX - початку XX століття
}

\section{О. В. Замуруйцев}

Мелітопольський державний педагогічний університет імені Богдана Хмельницького

\author{
Н. А. Шкода \\ Мелітопольський державний педагогічний університет імені Богдана Хмельницького
}

Ключові слова: іноземна колонізація; німецькі колоністи; меноніти; колоністське землеволодіння; сільське господарство; товарне виробництво; екстенсивний розвиток.
У статті, аналізуються історія дослідження соціально - економічного та культурного життя німецьких і менонітських поселень на прикладі території тогочасних Катеринославської та Таврійської губерній у середині XIX - на початку XX століття. Автори, спираючись на відповідний матеріал, зробили спробу визначити найбільш характерні риси й напрями розвитку цього процесу та з'ясувати його загальні тенденції. Аналізуючи загальну картину розвитку дореволюційної історіографії проблеми слід зазначити, що в цей період було закладено основи її вивчення $і$ створені умови для подальшого наукового дослідження.
The urgency of the chosen topic is determined by the need for further study of an important part of the general Ukrainian history, namely the history of small peoples inhabiting or inhabiting our multinational country. A prominent place among them was occupied by Germans and Mennonites, whose settlements appeared in the south of modern Ukraine in the late 18th and early 19th centuries as a result of the colonization policy of tsarist government. In the post-reform period, they played an important role in the economic development of the entire southern region. One of the aspects of this topic is the historiographical base of the study, which dates back to pre-revolutionary times. In many works of modern native and foreign researchers this issue has been given some attention. Most of researchers are considered the German colonization of the South Ukraine [1-4]. However, this topic is very bad considered as individual theme. A similar situation defined the purpose and objectives of this article. The aim of the paper is to consider the general history of the study of the life of the German-speaking community of the southern region of Ukraine in the middle of the nineteenth and early twentieth centuries, in native and foreign pre-revolutionary historiography, on the example of the contemporary Katerinoslav and Tavriya provinces (gubernia). The authors set the task to find the general features of this process and determine its most characteristics. One of the earliest examples of such literature is A. Klaus's study, which first presents the classic, to some extent, the textbook history of German colonization of the South Ukraine. According to the author, this colonization was caused not only by the corresponding policy of the Russian government, but also by the general specific situation prevailing in Germany at that time. A. Klaus first covered some aspects of the socio-economic life of the German and Mennonite colonies in the middle of the nineteenth century. In particular, relying on state audit materials, he pointed to the existence of a large number of landless colonists at the time and the mass nature of this phenomenon, he provided important data on colonial land tenure, agriculture, education, and the like. The researcher emphasized that the Germans and Mennonites dominated the form of land tenure. The researcher also pointed out that the general social situation in the colonies of the entire southern region at that time was rather complicated [5, p. 170-175]. A certain disadvantage of his work should be considered fragmentary, incomplete character of the given data, which in the majority at all (or almost at all) are not commented on by the author. Yet this study is important for national historiography, since it is one of the first attempts to comprehensively study the history of German and Mennonite colonies in Russia as an independent topic.

The problem of the Germans in Russia attracted the attention of another researcher of that time A. Velycin. He supplemented the study of his predecessor with the data of Zemstvo statistics of the middle of 1880-ies about the development of colonial land tenure in the South Ukraine. On the basis of these materials, the author concluded that the rapid spread of colonial land tenure throughout the Russian Empire in the post-reform period. A. Velicin was very critical of the fact of German colonization 
in Russia, believing that this led to the economic domination of the Germans in the country and had a negative impact on the local population. Despite the polemical nature of this conclusion, his work contains materials of a certain interest to our study. On concrete examples A. Velicin proved that it was the Russian nobility at that time was one of the main suppliers of land to German colonists in the southern region [6, pp. 26-27, 72-74].A more local character was noted by the study of D.A. Bagalyi, which covered the general history of the South Ukraine, and the "German question» was considered only as its component. According to the scientist, the high level of development of the economy in the German and Mennonite colonists and the rapid growth of their land tenure in the second half of the nineteenth century were largely due to the corresponding policy of the Russian government. The one for a long time provided colonists with significant privileges, while the closed nature of the existence of colonial settlements did not contribute to the dissemination of their advanced agricultures among the local population [7]. Among other works, which appeared at the end of the XIX century, one can mention the works of officials of the Tavriya province (gubernia) K. Werner, S. Kharizomenov and V.E. Postnikov. K. Werner and S. Harizomenov, based on the statistical material of the 80 's of the nineteenth century, for the first time made a comprehensive analysis of the contemporary socio-economic situation of the German colonies within the Melitopol district of the Tavriya province (gubernia). The value of this work is that the territory chosen by the authors for research is one of the then major centers of concentration of the German colonies in the southern region, therefore, the socio-economic processes that took place here, one way or another, were characteristic of the entire half-day of the German-speaking population of Ukraine. Exploring the economic situation of the colonies, these officials have repeatedly emphasized the higher level of agricultural development in the Germans, compared with other groups in the region. In their opinion, this was ensured due to the considerable size of colonial land tenure and the use of modern, as at that time, agricultural machinery by colonists. At that time, German farms had a clear focus on the production of grain crops. Analyzing the internal situation in the German and Mennonites settlements, researchers among the first noted the gradual deepening of social differentiation in the colonial environment, as well as the escalation of contradictions between wealthy and poor colonists [8].
K. Werner emphasized the significant influence of German farms on the development of agriculture in the entire southern region. It was, in particular, about the development and distribution by the Germans of more advanced agricultural machines, the withdrawal of new productive breeds of cattle, etc. These innovations, according to the researcher, gradually spread among peasants throughout the Tavriya province and beyond [9].

V.E. Postnikov are more critical of this problem. Like his predecessors, he also highly appreciated the contribution of the Germans and Mennonites to the economic development of the entire southern region. At the same time, in his opinion, their agriculture was not devoid of serious disadvantages, which for a long time remained without the attention of other researchers. This is, first and foremost, the one-sided development of colonial farms themselves, which are almost entirely oriented towards the production of grain crops, making other branches of agriculture unprofitable, which gradually depletes the soil and inevitably leads to reduced yields, routine farming, and so on. The researcher drew attention to certain mistakes in the works of his predecessors: in particular, they often lacked their own observations of peasant life, and the statistics they gave about the German colonists did not have a clear system. So, many digits with complex combinations that were used, such as $\mathrm{K}$. Werner, did not reproduce a complete picture of the economic development of the region. The successes of the Germans in the economic sphere were determined not by any particular features of their psychology or way of life, but primarily by economic reasons. According to V.E. Postnikov, they were hidden in the reluctance of the Germans to divide their land ownership between the heirs, although formally this rule has long been inactive. As a reverse example, he cited data from the German colonies of the Orenburg province, where this principle was forgotten and the local Germans quickly lost their preferences to other people, finding themselves in a very difficult economic situation.It is worth noting that V.E. Postnikov one of the first drew attention to the features of land stratification of the Germans and Mennonites. And it was precisely in the latter's attempt to minimize the harmful effects of such a stratification, the scientist saw one of the main reasons for the extensive internal land expansion of the Germans in the second half of the nineteenth century. to new territories and the transformation of German land tenure into a very influential economic power of a regional level. In analyzing this problem, the author noted that the 
increase in economic pressure gave rise to a certain confrontation between the Germans and the local peasants, which, however, was due not so much to the psychological or cultural factors as to the economic ones associated with the redistribution of land in the post-reform period [10, with. 192-195, 305-310].Interest in the German perspective has grown considerably in Russia at the beginning of the 20th century and on the eve of the First World War, which was reflected in new publications on this topic. Their authors, to a certain extent, continued to work in the direction begun by A. Klaus, and examined mainly the general issues of the history of German and Mennonite colonization in the country. Among such works, attention is drawn to the work of G. Pisarevskyi, in which he, relying on considerable volume of archival material, made an attempt to objectively analyze a number of problems associated with the phenomenon of German colonization in Russia. But, unfortunately, the researcher limited himself mainly to the early stage of foreign colonization in (by the middle of the XIX century) [11]. German land tenure in the South Ukraine at the beginning of the twentieth century. and, especially, during the First World War, became the object of study by such a researcher as K. Lindeman. In his opinion, the policy of the Russian government, aimed at limiting German land tenure during the war years, had a negative impact on the development of the colonial economy and the economy of the southern region as a whole [12].

Among the works devoted to the Mennonite subject, the study of Y.M. Bondar, who considered the history of Mennonite colonization in Russia (in particular, in the south of Ukraine), beginning with the end of the eighteenth century. He was one of the first to highlight the problem of the development of Mennonites land tenure in the post-reform period and other important aspects of the contemporary inner life of the Mennonite community, however, in our opinion, did not pay enough attention to the economic development of Mennonites settlements in the post-reform period [13]. At the same time, certain works of German-speaking authors were published, which came mainly from the local colonial clergy. They considered the history of their compatriots in Russia, first of all, through the prism of their spiritual life, but at the same time their research contained various materials concerning the internal life of the colonial communities of the South Ukraine. For example, E. Bush in his work drew attention to the development and state of education in the German Lutheran communities on the territory of the Russian Empire, in particular in the southern regions of modern Ukraine [14]. Another researcher, a former Lutheran priest Y. Shtah, described in his study the reasons for colonization, the government's policy on this issue, and his relationship with the colonists, adding to this the essay on the life of individual colonies [15]. About the life of the German Catholic colonies in this region was mentioned in the work of Pastor K. Keller, published in Odessa in 1905 [16]. These works complemented the work of the Mennonite historians of the late nineteenth and early twentieth centuries. D. Epp and F. Isaac, who presented the history of the Mennonite settlements of the South, considered the creation of new Mennonite communities, highlighted the activities of their separate prominent religious figures, the problem of the migration of Mennonites to new lands, etc. [17-18]. Analyzing the general picture of the development of pre-revolutionary historiography of this problem, it should be noted that in this period the foundations of its study were laid and conditions for further scientific research were created. As we see, pre-revolutionary work was mostly characterized by a narrative and a lack of a clear methodology for scientific research. Their authors most often were not professional historians, but some individuals who by their nature had one way or another to deal with the colonial environment. In their works, they relied on relevant documents of state audits and Zemstvo statistics, materials of colonial and departmental archives, legislative acts, etc., as well as their own observations.Among such literature, it is possible to trace two directions, which differed in character and separate accents in the study of the history of Germans and Mennonites in Russia. One of them, combining works devoted directly to the general history of German colonization in the Russian Empire (A. Klaus's works, A.A. Velicin, G.G. Pisarevsky and others). In them, the general-historical aspect of this problem directly dominated, and in many cases these studies only partly affected the southern regions of Ukraine. Another direction was related to the literature, which considered the German question only as an integral part of the whole history of the south of Ukraine, at its regional level and only in the general context of a certain theme (the works of K. Werner, S. Harizomenov, V.E. Postnikov). Much attention was paid here to more specific, in particular, economic issues, which were investigated with the help of considerable statistical material, which was gathered during the numerical Zemstvo censuses.It should be noted that, despite the insufficient scientific character of many such publications, they laid the foundations for further study of such im- 
portant issues as the proliferation of colonial land tenure in the South of Ukraine in the pre-reform period, the economic and social problems of the development of the German and Mennonite colonies of that time, the various aspects of their internal life and so on. Further study of this topic continued in the next (Soviet) period.

\section{References}

1. Безсонова 0.В. Позднее протестантское сектантство юга Украины (1850-1905 гг.): дис...канд. ист.наук: 07.00.01 / Оксана Володимирівна Безсонова.- Днепропетровск. ДГУ, 1997. - 257 с.

2. Бєлікова М.В. Менонітські колонії півдня України (1789 - 1917 рр.) - дис...канд. ист. наук: 07.00.01 / М.В. Бєлікова. - Запоріжжя, 2004. - 257 с.

3. Захарченко Т.К. Соціокультурний розвиток німецьких і менонітських колоній Північного Приазов'я (XIX - початок XX ст..): дис...канд. іст. наук. 07.00.02 / Таїсья Константинівна Захарченко.- Дніпропетровськ, 2005. - 225 с.

4. Bosch A., Lingor J. Entstehung, Entwicklung und Auflosung der deutschen Kolonien am Schwarzen Meer am Beispiel von Kandel 1808 bis 1944 / A.Bosch, J.Lingor. - Stuttgart, 1990. - 573 s.

5. Клаус А. Наши колонии / А. Клаус. - СПб.: Тип. В.В. Нусвольта, 1869. - 455 с.

6. Велицин Г.А. Немцы в Росии/ Г.А. Велицин. - СПб.: Изд. Русского вестника, 1893. - 282 с.

7. Багалей Д.И. Колонизация Новороссийского края и первые шаги его на пути культуры. Исторический этюд / Д.И. Багалей. - К.: Типография Корсакова-Новицкого, 1889. - 115 с.

8. Крестьянское хозяйство в Мелитопольском уезде. Составители К.Вернер и С.Харизоменов., - Ч. 1., - 0тд. 1., M. 1887. - 128+131+51 c.

9. Памятная книга Таврической губернии. Составитель К.А. Вернер.- Симферополь: Издательство Губернского Земства, 1889. - 76+107+124+69+73+68+73 с.

10. Постников В.Е. Южнорусское крестьянское хозяйство / В.Е. Постников - М., 1891. - 391 с.

11. Писаревский Г.Г. Из истории иностранной колонизации в России в XVIII ст. (по неизданным архивным документам). - М., 1909 г., - 340 с.

12. Линдеман К.Э. Прекращение землевладения и землевладение поселян-собственников: Указы 2 февраля - 13 февраля 1915 г. и 10, 15 июля и 19 августа 1916 г. и их влияние на экономическое состояние Южной России / К.Э. Линдеман. - М., 1917. - 384 с.

13. Бондарь Ю.М. Менониты / Ю.М. Бондарь. - Пг., 1915. - 252 с.

14. Busch E. Materialen yur Geschichte und Statistik des Kirchen $ß$ und Schulwesens der Ev. / E.Busch. -Lith., Gemenden in Rußland - St. Petersburg; G. Haeffel, 1862. -175 s.

15. Штах Я. Очерки из истории и современной жизни южно-русских колонистов / Я. Штах. - М., 1916. - 266 с.

16. . Keller C. Die deutschen Kolonien in Südrußland. Bd. 1-2 / C. Keller. - Odessa, 1890. - 460 s.

17. Epp D.H. Chortiser Mennonittn / D.H. Epp.- Odessa, 1889. - $196 \mathrm{s.}$

18. Isaac F. Die Molotschaner Mennoniten / F. Isaac.- Halbstadt, 1908. - 383 s. 